\title{
Fish derived bio-active peptides and their metabolic effects
}

\section{Balık kaynaklı biyo-aktif peptidler ve metabolik etkileri}

\author{
Can Altınelataman ${ }^{1 *}$ - Anna Torkova ${ }^{2}$ - Mikhail Tsentalovich ${ }^{2}$ \\ ${ }^{1}$ Ege University, Faculty of Fisheries, 35100, Bornova, Izmir, Turkey \\ 2Federal State Institution, Federal Research Centre, Fundamentals of Biotechnology of the Russian Academy of Sciences, Biochemistry Institute of Russian \\ Academy of Sciences, Moscow, Russia \\ *Corresponding Author: can.altinelataman@ege.edu.tr
}

How to cite this paper:

Altınelataman, C., Torkova, A., Tsentalovich, M., 2015. Fish derived bio-active peptides and their metabolic effects. Ege J Fish Aqua Sci 32(4): 217-223.

doi: 10.12714/egejfas.2015.32.4.08

\begin{abstract}
Özet: Diğer tüm organizmalar gibi, balıklar da, araştırmalarda antimikrobiyal, antihipertensif, antioksidan ve antitümör aktivitelerine odaklanılan bio-aktif bileşiklerin zengin kaynağıdırlar. Bunlar, sadece yüksek besin değeri nedeniyle değil, özellikle son yirmi yılda geliş̧tirien analitik yöntemlerle elde edilen peptidleri açısından da kullanılabilirler. Akuatik canlılar dünya üzerinde en fazla tür sayısına sahiptir, dolayısıyla bunlardan bio-aktif peptidlerin eldesi diğerlerine göre oldukça olasıdır ve bu, önceki çalışmalarda açıkça ortaya konmuştur. Doğal peptidler ve uzun zincirli polipeptidlerden uygun enzimatik yöntemlerle elde edilen peptidler tıp alanında yeni ufuklar açabilirler.
\end{abstract}

Anahtar kelimeler: Balık, peptidler, bio-aktif, metabolik etki, sağlık

Abstract: Like many other organisms, fishes are also rich sources of bio-active compounds which were well studied by research focused on their antimicrobial, antihypertensive, antioxidant and antitumor activities. They can be used not only for good nutritional value, but also for peptides obtained with analytic processes that were developed in last decades. Aquatic organisms total the highest number of species in world, therefore discovering bio-active peptides in them is more possible than in others, which was clearly shown in previous studies. Abundance of native and obtained peptides from long chain polypeptides with proper enzymatic methods may open new horizons for medical research.

Keywords: Fish, peptides, bio-active, metabolic effect, health

\section{INTRODUCTION}

In last decades many high-cost, time consuming studies were focused on fish derived peptides, their metabolisms and physiological effects on human health. They can be isolated from various foods like soy bean, milk and fish. Peptides are inactivated in main protein blocks till they are separated by enzymatic process and act as hormones in organisms. Bioactive peptides have gained importance with their potential for disease prevention and complex metabolic effects. Urotensin 1-2-3, adrenomedullin, melanin-concentrating hormone ( $\mathrm{MCH})$, piscidin and other novel peptides were obtained from various fish species. They, their receptors and human homologues are being investigated in last decade for human health topics for cancer, diabetes, hypertension, obesity, psychological and cardiovascular diseases. In this review, recent studies were presented about fish derived bio-active peptides, their human homologues and possible future targets which may develop new therapies for diseases, discussed. Definitely too many peptides are involved in metabolic processes. Hydrolysis is main procedure to obtain bio-active peptides from polypeptides with steps included hydrolysis, determining metabolic effects, purification, size separation, MS detection and sequencing of smaller than $10 \mathrm{kDa}$ (Ryan et al., 2011). According to Takahashi and Kawauchi (2004), fish peptides have important impacts on human physiology like appetite control, circulation, cell differentiation and on metabolic pathologies included cancer, metabolic syndrome and cardiovascular problems. They asked related question as 'if all living things began in water?' and stated that more studies should be carried out on his road to clarify relationships of these peptides with diseases to develop more effective therapies.

\section{Melanine-Concentrating Hormone (MCH)}

$\mathrm{MCH}$ is a regulating hormone for skin color of teleost fishes. It also can be found in mammalians central nervous system as a cyclic neuropeptide which has roles in complex network of stress-regulating system and appetite stimulating (Kawauchi et 
al., 1983; Flier, 2004; Takahashi et al. 2004). Takahashi et al.(2004) have reported salmon and human MCH sequencing (Fig.1). MCH is stimulator on food intake, may cause to obesity. Moreover, its role on homeostatis and brain activity was shown (Shi, 2004).

By binding to seven membrane receptors, neuropeptide $\mathrm{MCH}$ mediate its functions as neurotransmitter and regulator on food intake in mammals (Kawauchi, 2006). Matsuda et al. (2006) have reported that their results suggest that $\mathrm{MCH}$ influences feeding behavior, but not spontaneous locomotor activity, in the goldfish, and may exert an anorexigenic action in the goldfish brain, unlike its orexigenic action in mammals.

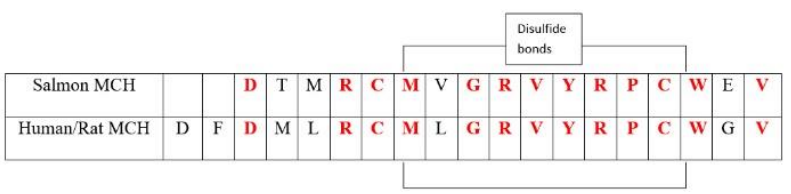

Figure 1. Aminoacid (AA) sequences of human and fish $\mathrm{MCH}$ (Takahashi, 2004)

\section{Epinecidin}

An antimicrobial fish peptide Epinecidin-1 has also an antitumor effect in human fibrosarcoma cells. Effects of epinecidin-1 on cell membranes of tumor cells were shown (Lin et al. 2009; Hoskin and Ramamoorthy, 2008). 21 AA contained (GFIFHIIKGLFHAGKMIHGLV) peptide epinecidin-1 (Rajanbabu and Chen, 2011) was evaluated by various study and researches for its spesifications mentioned above. Fish can regulate their defense system while cytokine expressions, bacterial infection consequences and protect them from death by injection of epinecidin-1 peptide just before inoculation of V.vulnificus according to Pan et al. (2007). Same infection were prevented in grouper (Epinephelus coioides) and zebrafish (Danio rerio) by epinecidin-1, reported Pan et al. (2012).

\section{Adrenomedullin (AM)}

Adrenomedullin is a member of Calcitonin Gene Related Peptide (CGRP) family. Five paralogues of AM are identified in teleost fishes (Fig 2a). One of these, AM2, may be more advantageous than AM to respond quickly to changes in blood flow and oxygen content in the coronary artery. If this is actually the case, then AM2 can be used as a diagnostic marker for the initial stage of ischemic heart failure (Fig 2b) (Takei et al., 2004a). Comparative genomic analyses concluded that mammalian AM2 is an ortholog of pufferfish AM2 (Takei et al., 2004b).

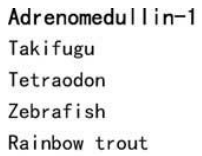

Takifugu HANNGGGRSHGQLMRVACVLGTCQVONLSHRLYQLI GQSGKEDSSPMNPHSPHSY-NH2 Zebrafish HAFRG-SRGHPQLMRVGCVLGTCQVONLSHRLYQLNSQSRRQES-PINPRSPHSY-NH2 Rainbow trout HANGSGGRGQGQLMRVGCVLGTCQVQNLSHRLYQLI GQSGRQDSSPINPRSPHSY-NH2

Adrenomedull in-3

Tak i fugu HIHSRGHHYPHPNQL IRAGCALGTCQVONLSHRLYQLIGQSGRDDSSPINPKSPHSY-NH2 Tetraodon YVHSRGSRGHHQNQLMRVGCVLGTCOVQNLSHRLYQLIGQSGREDSSPMNPQSPHSY-NH2 Zebrafish HVHSRGHHSHHHPQLMRVGCVLGTCQVONLSHRLYQLVGQSGREDS-PINPRSPHSY-NH2

Adrenomedull in-4

Takifugu

Tetraodon

Zebrafish

Adrenomedul I in-5

Takifugu

Tetraodon

Zebrafish

Rainbow trout

Figure 2a. Amino acid sequences of five putative mature peptides of the adrenomedullin (AM) family identified in teleost fish (Takei et al., 2004a)

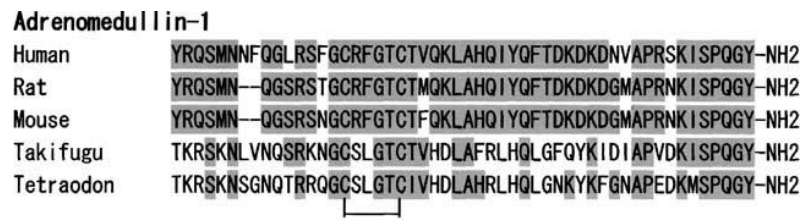

Adrenomedullin-2

Human

Rat

Mouse

Takifugu

Tetraodon

TOAQLLRVGCVLGTCOVONLSHRLWOLMGPAGRODSAPVDPSSPHSY-NH2 PHAQLLRVGCVLGTCQVONLSHRLWQLVRPSGRRDSAPVDPSSPHSY-NH2 PHAQLLRVGCVLGTCQVONLSHRLWOLVRPAGRRDSAPVDPSSPHSY-NH2 SHGQLMRVACVLGTCQVONLSHRLYQLIGOSGKEDSSPMNPHSPHSY-NH2 HONOLMRVGCVLGTCOVONLSHRLYQLIGQSGREDSSPMNPOSPHSY-NH2

Figure $\mathbf{2 b}$. Amino acid sequences of adrenomedullin (AM) 1 and 2 in human, rat, mouse and two species of pufferfish (Takifugu rubripes and Tetraodon nigroviridis) (Takei et al., 2004a)

\section{Ghrelin}

Ghrelin was isolated from goldfish and it is naturally secreted by stomach and hypothalamic neurons now recognized as a multifunctional peptide for human feeding, cardiovascular and pshycological metabolisms (Currie et al., 2008; Miura et al., 2009). Ghrelin has also electrophysiological effects on pedunculopontine tegmental neurons in rats (Kim et al., 2009).

Unniappan and Peter (2005) have indicated about ghrelin functions on fish as regulator of food intake, growth hormone production, reproduction and other physiological metabolisms as well as in mammals similar pathways and still need to be researched for endocrinology database to better understanding. According to Kang et al. (2011) stated about differencies in metabolism of ghrelin on same or different teleost fishes like energy intake, locomotor mechanisms and fat deposition. Further studies to be needed about effects on homeostatic function. 


\section{Urotensin}

Urotensin 1 was first isolated in pure form from an extract of urophyes of the white sucker (Catostomus commersoni). Its human homologues urocortins (UCNs) produces a hypotensive response, acts as a mediator of the effects of stress on food intake and may play protective roles against cardiovascular stress (Conlon, 2000; Inada et al., 2009). Urotensin 2 is a cyclic peptide also isolated from fish and expressed in some tumor cells, and stimulates proliferation of them (Takahashi et al. 2004). UCNs have also functions in energy, gastrointestinal, immune, reproductive systems and hearing (Fekete and Zorilla, 2007).

\section{Hepcidin}

Hepcidin is well known peptide that has roles in iron metabolism and defense mechanism against bacterial infections (Rodrigues et al., 2006). Chen et al. (2009) have indicated that Tilapia hepcidin (TH2-3) may be promising candidate for treatment of cancer with its cytotoxic effects on destructive impact on membranes of cancer cells and downregulation of apoptosis gene expression, blocking invasion to prevent metastasis, especially on human fibrocarcinoma cells (Chen et al, 2009). Rodrigues et al. (2006) have detected 8 copies of hepcidin gene in sea bass genome and determined its functions on iron regulation and infection response.

\section{Piscidin}

Piscidins are one of the elements in antiviral defence system of fish. They can also act like antibiotics and help fighting viruses in human body. Peptide antibiotics, host-produced antimicrobial defenses that have been isolated from all types of organisms, from plants to mammals, possess a number of characteristics that make them attractive drug candidates. An example of the diversity and potential for new discoveries in this area is a novel family of peptide antibiotics named "piscidins," which have been recently isolated from fish. Piscidins have potent, broad-spectrum in vitro activity against many pathogens, including multidrug-resistant bacteria (Noga and Silphaduang, 2003). Sung et al. (2008) have stated that piscidin 1 (P1) has more effective in fungicidal and hemolytic activities than piscidin 3 (P3), in addition, P1 also have higher ability to permeabilize phospholipids membranes where action of peptides performed. Antimicrobial effects of $\mathrm{P} 1$ and $\mathrm{P} 3$ by minimum concentration were summarized at Table1 (Chekmenev et al, 2006).

Table 1. Minimum inhibitory concentration of $P 1$ and $P 3$ on microorganisms (Chekmenev et al., 2006)

\begin{tabular}{|l|l|l|}
\hline Microorganism & P1-MIC $(\mu \mathrm{M})$ & P-3-MIC $(\mu \mathrm{M})$ \\
\hline Gram (+) & & \\
Staphylococcus aureus & $0-2$ & $0-2$ \\
Bacillus cereus & $0-2$ & $2-10$ \\
\hline Gram (-) & & \\
Escherichia coli & $2-10$ & $10-20$ \\
Proteus vulgaris & $2-10$ & $2-10$ \\
& & \\
\hline
\end{tabular}

\section{Calcitonin (CT)}

Calcitonin is a member of CGRP (Calcitonin Gene-Related Peptides) superfamily like amylin, adrenomedullins and CRSPs (Calcitonin receptor-stimulating peptides). Calcitonin, a 32 aa peptide, was initially isolated from fish. Fish CT has higher affinity to mammalian CT receptor (CTR), and has activity on calcium homeostatis. Therefore, fish CT has been used as a drug for treatment of human bone diseases (Nag et al, 2007). Pufferfish and mammalian CTR genes have miR-489 coding region in intron 3. Although the function of miR-489 has not been clarified yet. Its expression was detected in brain and eye (Kloosterman et al., 2006). Its suggesting role in nervous system (Nag et al, 2007).

MCH (Melanin Concentrating Hormone) stimulates apetit which leads to obesity may cause diabetes mellitus which prevented by U-II (Urotensin II) that also has cardiovascular control and inhibiting effect on tumoral cell growth. Possible relations, interactions of fish derived peptides to human physiology and diseases with other mechanisms were shown at Fig 3 (Takahashi, 2004).

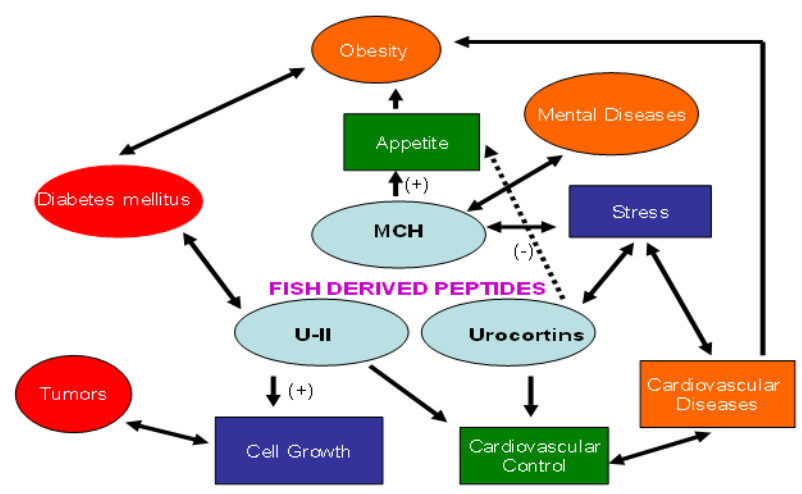

Figure 3. Possible relations, interactions of fish derived peptides and related metabolic processes (Takahashi, 2004)

\section{Novel Peptides}

The in vitro colony formation activity of established human tumor cells (HT-29: Colon cancer cells, MDA-MB-231: Breast cancer cells) is greatly reduced or diminished by treatment with rtEa-4, one of trout pro-IGF-I E-peptides. The invasive activity of HT1080 (invasive cancer line cells) is reduced three to fourfold by treatment with the same peptide (Chen et al., 2002).

The peptide MY isolated from sardine, stimulates antioxidant protein HO-1 (heme oxygenase) activity (Erdmann et al., 2006).

18 fish protein hydrolysates from Atlantic salmon (Salmo salar), Atlantic cod (Gadus morhua), plaice (Pleuronectes platessa), bluewhiting (Micromesistius poutassou), Atlantic emperor (Lethrinus atlanticus), pollack (Pollachius pollachius) and Portuguese dogfish or siki (Centroscymnus coelolepis) were measured on 2 human breast cancer lines grown in vitro. They were identified as significant growth inhibitors on the two cancer lines (Picot et al., 2006).

The fish muscle hydrolysate of 300-700 Da molecular weight showed high ACE (Angiotensin Converting Enzyme) inhibitory 
(regulation of blood pressure) and radical scavenging activity. Coho salmon is the most effective sample to obtain bio-active compounds (Nakajima et al., 2009)

Protein hydrolysate from blue whiting (Micromesistius poutassou) by-product, stimulates CCK (Cholecystokinin) secretion in the STC-1 (intestinal edocrine cells) and appetitesuppressive effect to control the body weight (Cudennec et al., 2008).

The acidic mucus extracts of brook trout, haddock and hagfish showed antibacterial activity against a wide range of fish and human pathogens (Subramanian et al., 2008).

Oral administration of fish protein concentrates (FPC) enhances gut-associated non-specific immunity without an inflammatory outcome and that this effect would be induced by the products appeared during the fermentation process. FPC is an immunomodulating food with a demonstrated capacity to enhance non-specific host defence mechanism (Duarte et al., 2006)

With the hydrolysate obtained from fresh sample, the bioactive molecules around $1850 \mathrm{Da}$ also interacted with the CGRP receptor in rat liver membranes. We can conclude they are structurally very similar to human CGRP. The obtained molecules (gastrin/CCK-and- CGRP-like peptides) could make the cod hydrolysates useful for incorporation in functional foods (Slizyte et al., 2009).

Song et al. (2012) have discovered peptides (MLTTPPHAKYVLQW, LRSKAAAPAEQYE, TPGALLEHPTL,
SHAATKAPPKNGNY, LATVSVGAVELCY, PTAGVANALQHA, QLGTHSAQPVPF, VNVDERWRKL, NPEFLASGDHLDNLQ, PEVVYECLHW) from half-fin anchovy (Setipinna taty) and reported that pepsin hydrolysate of the marine fish half-fin anchovy contained antibacterial peptide fractions. HAHp2-3-I, an antibacterial peptide fraction whose molecular weight ranges from 1,100 to 1,700 Da was isolated and characterized. Peptides sequences prediction showed that HAHp2-3-I contained net charged peptides, which could form extended strands, random coils and alpha helix structures. HAHp2-3-I might exert its antibacterial activity via a membrane disruptive model in the "carpet" model way.

Kumanesan et al. (2015) have reported that a novel antimicrobial peptide had been derived from goose type lysozyme (LyzG) which was identified from the cDNA library of freshwater fish Channa striatus (Cs ). The identified lysozyme cDNA contains 585 nucleotides which encodes a protein of 194 amino acids

Sila et al. (2014), evaluated the mode of action of new peptides (Gly-Val-His, Trp-His-Arg, Trp-His-Phe, Pro-Pro-Ser-Ser, AlaAla-Ala-Leu, Ala-Ala-Gly-Gly-Val, Ala-Ala-Val-Lys-Met, AlaSer-Ser-Ser), previously characterized, from barbel (Barbus callensis) protein hydrolysates against Listeria monocytogenes via a membrane damage mechanism. Prediction of peptide secondary structure indicated that these peptides should have random coil structures and high content of hydrophobic amino acids (Table 2).

Table 2. Antibacterial activity of synthetic peptides ( $1 \mathrm{mg} / 1 \mathrm{ml})$ (Sila et al., 2014)

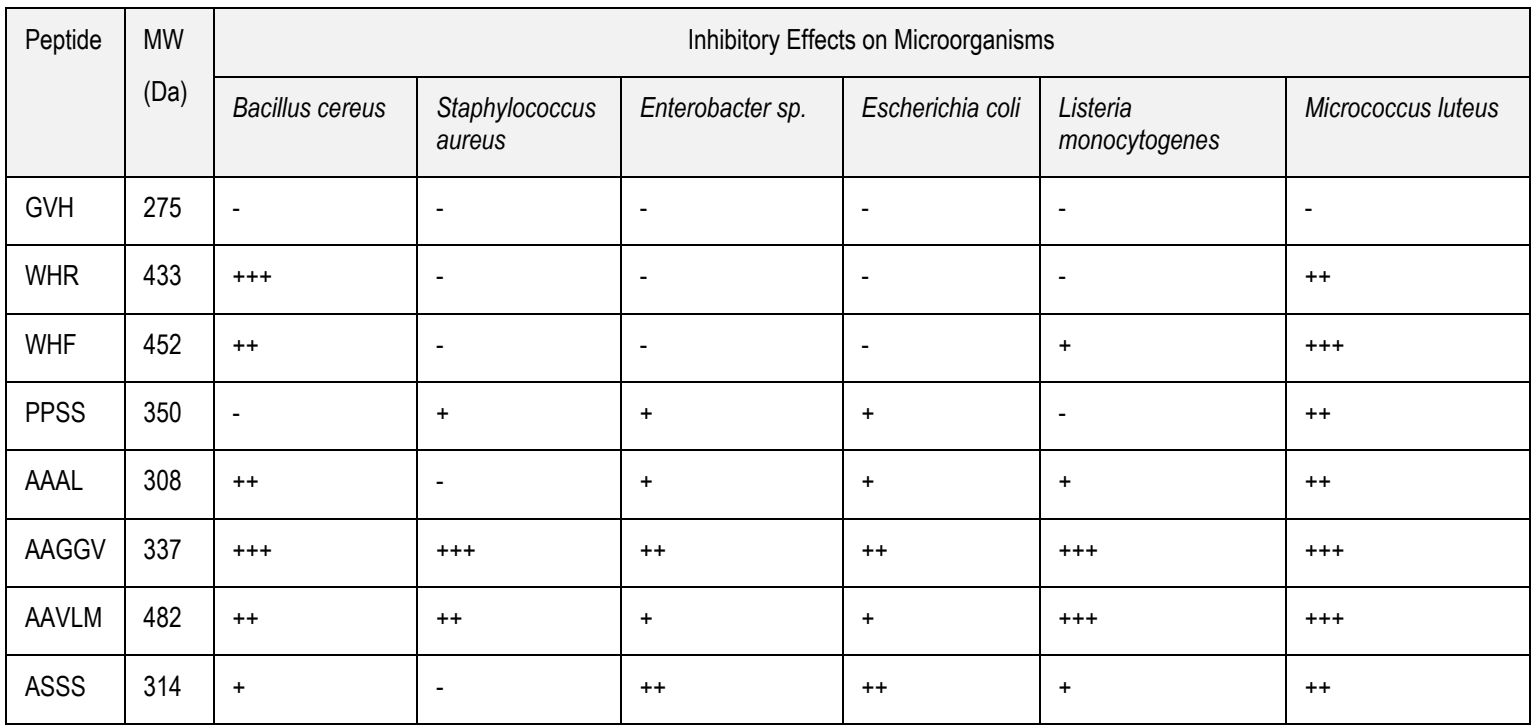

Àlvarez et al (2014) have reported on antimicrobial activity of trout hepcidin and stated that peptide showed an alfa-helix conformation in reduced state and the characteristic beta-sheet conformation in the oxidized state. Antimicrobial activity assays showed that the oxidized peptide is more effective than the reduced peptide against Escherichia coli and the important salmon fish pathogen Piscirickettsia salmonis.
Valero et al. (2015) have reported that they characterized the antimicrobial response triggered by nodavirus (VNNV) in the testis of European sea bass (Dicentrarchus labrax), a very susceptible species of the virus, and in the gilthead seabream, which acts as a reservoir, both in vivo and in vitro, and compared with that present in the serum and brain (target tissue of VNNV). First, their data show a great antiviral 
response in the brain of gilthead seabream and in the gonad of European sea bass. In addition, for the first time, their results demonstrate that the antimicrobial activities (complement, lysozyme and bactericidal) and the expression of AMP genes such as complement factor 3 , lysozyme, hepcidin, dicentracin, piscidin or b-defensin in the gonad of both species are very different, but generally activated in the European sea bass.

Wang et al. (2015), characterized the gene structure and expression of MHC class II (Lunar-DAA) and II (Lunar-DAB) of mangrove red snapper (Lutjanus argentimaculatus). Both genes shared, respectively, a high similarity and typical features with other vertebrate MHC class II $\alpha$ and II $\beta$. The phylogenetic analysis of the deduced peptides revealed that both Lunar-DAA and Lunar-DAB were located in the teleost subclass. Western blotting analyses indicated that both $\mathrm{MHC}$ class II $\alpha$ and II $\beta$ were expressed ubiquitously in immunerelated cells, tissues and organs, and that MHC class II $\alpha$ and II $\beta$ chains existed mainly as heterodimers. While it was highly expressed in gills, thymus, head kidney (HK), spleen, head kidney macrophage and spleen leucocytes, MHC class II $\beta$ chain was expressed with a low abundance in skin, intestine, stomach and heart.

Lassoued et al. (2015) have used Neutrase and Alcalase to obtaine thornback ray (Raja clavata) muscle hydrolysates (TRMH). They have reported that TRMH-Neutrase exhibited the highest antioxidant activity in DPPH (2,2-diphenyl-1picrylhydrazyl) scavenging, reducing power and inhibition of $\beta$ carotene bleaching tests. However, in the total antioxidative efficacy, TRMH-Crude exhibited the highest activity. TRMHCrude and TRMH-Neutrase were the most potent to prevent DNA oxidation by Fenton reagent. Concerning anti-ACE activity, TRMH-A26 and TRMH Neutrase exhibited the highest activity with $87 \%$ at $5 \mathrm{mg} / \mathrm{ml}$.

Liu et al. (2014) have reported comprehensive analysis and characterization of LEAP-2 gene from miiuy croaker (Miichthys miiuy). In their study, cDNA of miiuy croaker was completely analysed and determined LEAP-2 gene as $2360 \mathrm{bp}$, contained $170 \mathrm{bp}$ at 5 'terminal untranslated region (UTR), an part of open reading frame (ORF) of 312 bp, 1878 bp at 3' terminal (UTR).

LEAP-2 of this fish has shown anti-microbial activity on Aeromonas hydrophila. Moreover, with evolutionary analysis to predict selective constraints. It was determined that no positive selection detected for sequences of LEAP-2 gene.

Chalamaiah et al. (2015) have use eggs of common carp (Cyprinus carpio) to obtain hydrolysates by using pepsin, trypsin and Alcalase. Its determined that all hydrolysates significantly boosted proliferation of spleen lymphocytes where pepsin hydrolysate $(0.5 \mathrm{~g} / \mathrm{kg}$ body weight) has significant impact on increasing the cytotoxicity of splenic killer cells and $\lg A$ too. Alcalase hydrolysate enhanced the percentage of CD4+ and CD8+ cells in spleen.

Henda et al. (2015) have investigated effects of previously known peptides on proliferation, differentiation and maturation of human white pre-adipocytes. They indicated that adipocytes can be affected in different stages of their life cycle by some marine peptides but this is not correlated with their inhibiting ability on ACE (Angiotensin Converting Enzyme). (Leu-LysPro) and (Val-Tyr) have high ACE inhibiting capability but no proliferation or differentiation effect on adipocyte cells. Inhibition of preadipocytes growth could be induced during proliferation by three peptides sequenced as (Ala-Pro), (ValAla-Pro) and (Ala-Lys-Lys). In other stage; differentiation, number of preadipocytes may decreased by two peptides as (Lys-Trp-Trp) and (Val-Trp). By restriction of factors for adipocyte specific transcription, (Gly-Pro-Leu) or (lle-Tyr) could inhibite adipogenesis.

Azuma et al. (2014) have extracted fish scale collagen peptide and investigated its anti-inflammatory effects in the dextran sulfate sodium induced acute ulcerative colitis model and stated that their results indicate that fish scale collagen peptides could be a new functional food for patients with inflammatory bowel disease.

$\mathrm{Fe}(\mathrm{II})$-binding activity ability of fish scale collagen peptides were detected by Huang et al. (2015) as primary study on this concept, also indicated that scales could be proper source for fish collagen.

Salampessy et al. (2015) have produced three bioactive peptides from hydrolyzation of trevally (Pseudocaranx $\mathrm{sp}$.), investigated their ACE-Inhibitory effects and stated that fractionation with RP-HPLC gave three most active peptide fractions labelled as TBS1, TBS2, and TBI2 which showed high potential as ACE-inhibitory agents. Sequences of active peptides were detected as

AR, AV, and APER, with molecular weights of 245.28, 188.23, and $471.51 \mathrm{Da}$, respectively. Their stability in gut were shown by simulated gastrointestinal enzyme degradation.

Ennaas et al (2015) have obtained four bioactive peptides from Atlantic mackerel (Scomber scombrus) hydrolizate, that sequenced as SIFIQRFTT (P4), RKSGDPLGR (P8.1), AKPGDGAGSGPR (P8.2) and GLPGPLGPAGPK (P11). They reported that P8.1, P8.2 and P11 exhibited partial inhibition, P4 totally inhibited tested Gram-positive (Listeria innocua) and Gram-negative (Escherichia coli) bacterial strains.

García-Moreno et al (2015) have identified 14 novel ACEinhibitory peptides in horse mackerel and small-spotted catshark hydrolysates. The peptide VAMPF, identified in fraction $D$ of smallspotted catshark hydrolysate, is evaluated as one of the most promising peptides.

\section{CONCLUSION}

Fish derived bio-active peptides are gaining importance among all scientific community that related human health like pharmacy, biochemistry and medicine. Their high nutraceutical, pharmaceutical and disease prevention potentials may make possible to produce products in food industry like nourishment 
support and in medicine like vaccines. New modelling concepts on the way with developing techniques to solve their structures and creating artificial active forms of polypeptide subunits as mimicked oligopeptides and peptides. It's clearly that

\section{REFERENCES}

Àlvarez, C.A., Guzmàn, F., Càrdenas, C., Marshall, S.H., Mercado, L., 2014 Antimicrobial activity of trout hepcidin. Fish \& Shellfish Immunology, 41:93101. doi: 10.1016/j.fsi.2014.04.013

Azuma, K., Osaki, T., Tsuka, T., Imagawa, T., Okamoto, Y., Minami, S., 2014. Effects of fish scale collagen peptide on an experimental ulcerative colitis mouse model. PharmaNutrition, 2:161-168. doi: 10.1016/j.phanu.2014.10.001

Chalamaiah, M., Hemalatha, R., Jyothirmayi, T., Diwan, P.V., Bhaskarachary, K., Vaireswari, A., Kumar, R.R., Kumar, B.D., 2015. Chemical composition and immuno modulatory effects of enzymatic protein hydrolysates from common carp (Cyprinus carpio) egg. Nutrition, 31:388-398. doi: 10.1016/j.nut.2014.08.006

Chekmenev, E.Y., Vollmar, B.S., Forseth, K.T., Manion, M.N., Jones, S.M., Wagner, T.J., Endicott, R.M., Kyriss, B.P., Homem, L.M., Pate, M., He, J., Raines, J., Gor'kov, P.L., Brey, W.W., Mitchell, D.J., Auman, A.J., EllardIvey, M.J., Blazyk, J., Cotten, M., 2006. Investigating molecular recognition and biological function at interfaces using piscidins, antimicrobial peptides from fish. Biochimica et Biophysica Acta, 1758(9):1359-1372. doi: 10.1016/j.bbamem.2006.03.034

Chen, M. J., Kuo, Y. H., Tian, X. C., Chen, T. T., 2002. Novel biological activities of the fish pro-IGF-I E-peptides: studies on effects of fish pro-IGF-I Epeptide on morphological change, anchorage-dependent cell division, and invasiveness in tumor cells. General and Comarative Endocrinology,126: 342-351. doi: 10.1016/S0016-6480(02)00010-2

Chen, J-Y., Lin, W-J., Lin, T-L., 2009. A fish antimicrobial peptide, tilapia hepcidin TH2-3, shows potent antitumor activity against human fibrosarcoma cells. Peptides, 30(9):1636-1642. doi: 10.1016/j.peptides.2009.06.009

Conlon, J.M., 2000. Singular contributions of fish neuroendocrinology to mammalian regulatory peptide research. Regulatory Peptides, (93):3-12 doi: 10.1016/S0167-0115(00)00172-5

Cudennec, B., Ravallec-Plé, R., Courois, E., Fouchereau-Peron, M., 2008. Peptides from fish and crustacean by-products hydrolysates stimulate cholecystokinin release in STC-1 cells. Food Chemistry, 111(4):970-975. doi: 10.1016/j.foodchem.2008.05.016

Currie, P.J., Grueneisen, A.M., Wall, D.G., Sarkodie, K.A., 2008. Anxiogenic, orexigenic and metabolic effects of hypothalamic ghrelin. Appetite, 51 : 360. doi: 10.1016/j.appet.2008.04.062

Duarte, J., Vinderola, G., Ritz, B., Perdigon, G., Matar, C., 2006. Immunomodulating capacity of commercial fish protein hydrolysate for diet supplementation. Immunobiology, 211:341-350. doi: 10.1016/j.imbio.2005.12.002

Ennaas, N., Hammami, R., Beaulieu, L., Fliss, I., 2015. Purification and characterization of four antibacterial peptides from protamex hydrolysate of Atlantic mackerel (Scomber scombrus) by-products. Biochemical and Biophysical Research Communications, 462:195-200. doi: 10.1016/j.bbrc.2015.04.091

Erdmann, K., Grosser, N., Schipporeit, K., Schro, H., 2006. The ACE Inhibitory Dipeptide Met-Tyr Diminishes Free Radical Formation in Human Endothelial Cells via Induction of Heme Oxygenase-1 and Ferritin. The Journal of Nutrition, 36:2148-2152.

Fekete, E.M., Zorrilla, E.P., 2007. Physiology, pharmacology, and therapeutic relevance of urocortins in mammals: Ancient CRF paralogs. Front Neuroendocrinology, 28:1-27. doi: 10.1016/j.yfrne.2006.09.002

Flier, J., 2004. Obesity Wars: Molecular Progress Confronts an Expanding Epidemic. Cell, 116: 337-350. doi: 10.1016/S0092-8674(03)01081-X

Garcia-Moreno, P.J., Espejo-Carpio, F.J., Guadix, A., Guadix, E.M., 2015 Production and identification of angiotensin I-converting enzyme (ACE) humankind could find solutions for pathologies in nature by completing billion pieces puzzle where bio-active peptides takes leading roles as big part by future visions with sophisticated methods and devices.

inhibitory peptides from Mediterranean fish discards. Journal of Functional Foods, 18:95-105. doi: 10.1016/j.jf.2015.06.062

Henda,Y.B., Laamari, M., Lanneluc, I., Travers, M-A., Agogué, H., Arnaudin, I., Bridiau, N., Maugard, T., Piot, J-M., Sannier, F., Bordenave-Juchereau, S., 2015. Di and tripeptides from marine sources can target adipogenic process and contribute to decrease adipocyte number and functions. Journal of Functional Foods, 17:1-10. doi: 10.1016/j.jf.2015.04.050

Hoskin, D.W., Ramamoorthy, A., 2008. Studies on anticancer activities of antimicrobial peptides. Biochimica et Biophysica Acta (BBA) Biomembranes, 1778(2): 357-375.

Huang, C-Y., Wu, C-H., Yang, J-I., Li, Y-H., Kuo, J-M., 2015. Evaluation of ironbinding activity of collagen peptides prepared from the scales of four cultivated fishes in Taiwan. Journal of Food and Drug Analysis, 23(4):671678. doi: 10.1016/j.jfda.2014.06.009

Inada, Y., Ikeda, K., Tojo, K., Sakamoto, M., Takada, Y., Tajima, N., 2009. Possible involvement of corticotropin-releasing factor receptor signaling on vascular inflammation. Peptides, 30:365-372.

doi: 10.1016/j.peptides.2008.10.015

Kang, K-S., Yahashi, S., Matsuda, K., 2011. Central and peripheral effects of ghrelin on energy balance, food intake and lipid metabolism in teleost fish. Peptides, 32: 2242-2247. doi: 10.1016/j.peptides.2011.05.006

Kawauchi, H., 2006. Functions of Melanin-Concentrating Hormone in Fish. Journal of Experimental Zoology, 305A:751-760. doi: 10.1002/jez.a.310

Kawauchi, H., Kawazoe, I., Tsubokowa, M., Kishida, M., Baker, B.I., 1983. Characterization of melanin-concentrating hormone in chum salmon pituitaries. Nature, 305:321-323. doi: 10.1038/305321a0

Kim, J., Nakajima, K., Oomura, Y., Wayner, M.J., Sasaki, K., 2009. Electrophysiological effects of ghrelin on pedunculopontine tegmental neurons in rats: An in vitro study. Peptides, 30(4): 745-757. doi: 10.1016/j.peptides.2008.12.004

Kloosterman, W.P., Steiner, F.A., Berezikov, E., Bruijn, E., Belt, J., Verheul, M., Cuppen, E., Plasterk, R.H.A., 2006. Cloning and expression of new microRNAs from zebrafish. Nucleic Acids Research, 34(9): 2558-2569. doi: 10.1093/nar/gkl278

Kumanesan, V., Bhatt, P., Ganesh, M-R., Harikrishnan, R., Arasu, M., Al-Dhabi, N.A., Pasupuleti, M., Marimuthu, K., Arockiaraj, J., 2015. A novel antimicrobial peptide derived from fish goose type lysozyme disrupts the membrane of Salmonella enterica. Molecular Immunology, 68(2B):421-433. doi: 10.1016/j.molimm.2015.10.001

Lassoued, I., Mora, L., Nasri, R., Aydi, M., Toldrà, F., Aristoy, M-C., Barkia, A., Nasri, M., 2015. Characterization, antioxidative and ACE inhibitory properties of hydrolysates obtained from thornback ray (Raja clavata) muscle. Journal of Proteomics, 128:458-468. doi: 10.1016/j.jprot.2015.05.007

Lin, W-J., Chien, Y-L., Pan, C-Y., Lin, T-L., Chen, J-Y., Chiu, S-J., Hui, C-F., 2009. Epinecidin-1, an antimicrobial peptide from fish (Epinephelus coioides) which has an antitumor effect like lytic peptides in human fibrosarcoma cells. Peptides, 30(2):283-290. doi: 10.1016/j.peptides.2008.10.007

Liu, T., Gao, Y., Wang, R., Xu, T., 2014. Characterization, evolution and functional analysis of the liver- expressed antimicrobial peptide 2 (LEAP2) gene in miiuy croaker. Fish \& Shell fish Immunology, 41:191-199. doi: 10.1016/j.fsi.2014.08.010

Matsuda, K., Shimakura, S-I., Maruyama, K., Miura, T., Uchiyama, M., Kawauchi, H., Shioda, S., Takahashi, A., 2006. Central administration of melanin-concentrating hormone $(\mathrm{MCH})$ suppresses food intake, but not locomotor activity, in the goldfish, Carassius auratus. Neuroscience Letters, 339 (3):259-263. 
Miura, T., Maruyama, K., Kaiya, H., Miyazato, M., Kangawa, K., Uchiyama, M. Shioda, S., Matsuda, K., 2009. Purification and properties of ghrelin from the intestine of the goldfish, Carassius auratus. Peptides, 30(4): 758-765. doi: 10.1016/j.peptides.2008.12.016

Nag, K., Kato, A., Sultana, N., Ogoshi, M., Takei, Y., Hirose, S., 2007. Fish calcitonin receptor has novel features. General and Comparative Endocrinology, 154(1-3): 48-58. doi: 10.1016/j.ygcen.2007.06.017

Nakajima, K., Yoshie-Stark, Y., Ogushi, M., 2009. Comparison of ACE inhibitory and DPPH radical scavenging activities of fish muscle hydrolysates. Food Chemistry, 114(3):844-851. doi: 10.1016/j.foodchem.2008.10.083

Noga, E.J., Silphaduang, U., 2003. Piscidins: a novel family of peptide antibiotics from fish. Drug News Perspect, 16(4): 87-92. doi: 10.1358/dnp.2003.16.2.829325

Pan, C-Y., Chen, J-Y., Cheng, Y-S.E., Chen, C-Y., Ni, I-H., Sheen, J-F., Pan,YL., Kuo, C-M. 2007. Gene Expression and Localization of the Epinecidin1 Antimicrobial Peptide in the Grouper (Epinephelus coioides), and Its Role in Protecting Fish Against Pathogenic Infection. DNA and Cell Biology, 26(6): 403-413. doi: 10.1089/dna.2006.0564

Pan, C-Y., Huang, T-C., Wang, Y-D., Yeh, Y-C., Hui, C-F., 2012. Oral administration of recombinant epinecidin-1 protected groupe (Epinephelus coioides) and zebrafish (Danio rerio) fromVibrio vulnificus infection and enhanced immune-related gene expressions. Fish \& Shellfish Immunology, 32: 947-957.

Picot, L., Bordenave, S., Didelot, S., Fruitier-Arnaudin, I., Sannier, F., Thorkelsson, G., Berge, J.P., Guerard, F., Chabeaud, A., Piot, J.M., 2006. Antiproliferative activity of fish protein hydrolysates on human breast cancer cell lines. Process Biochemistry, 41:1217-1222. doi: 10.1016/j.procbio.2005.11.024

Rajanbabu, V., Chen, J-Y., 2011. Applications of antimicrobial peptides from fish and perspectives for the future. Peptides, 32:415-420. doi: 10.1016/j.peptides.2010.11.005

Ryan, J.T., Ross, R.P., Bolton, D., Fitzgerald, G.F., Stanton, C., 2011. Bioactive Peptides from Muscle Sources: Meat and Fish. Nutrients, 3(9): 765-791. doi:10.3390/nu3090765

Rodrigues, P.N.S., Vázquez-Doradoa, S., Neves, J.V., Wilson, J.M., 2006. Dua function of fish hepcidin: Response to experimental iron overload and bacterial infection in sea bass (Dicentrarchus labrax). Developmental and Comparative Immunology, 30: 1156-1167. doi: 10.1016/j.dci.2006.02.005

Salampessy, J., Reddy, N., Kailasapathy, K., Phillips, M., 2015. Functional and potential therapeutic ACE-inhibitory peptides derived from bromelain hydrolysis of trevally proteins. Journal of Functional Foods. 14:716-725 doi: 10.1016/j.jf.2015.02.037

Shi, Y., 2004. Beyond skin color: emerging roles of melanin-concentrating hormone in energy homeostasis and other physiological functions. Peptides, 25(10): 1605-1611. doi: 10.1016/j.peptides.2004.02.023

Slizyte, R., Mozuraityte, R., Martinez-Alvarez, O., Falch, E., FouchereauPeron, M., Rustad, T. 2009. Functional, bioactive and antioxidative properties of hydrolysates obtained from cod (Gadus morhua) backbones. Process Biochemistry, 44:668-677. doi: 10.1016/j.procbio.2009.02.010

Sila, A., Hedhili, K., Przybylski, R., Ellouz-Chaabouni, S., Dhulster, P., Bougatef, A., Nedjar-Arroume, N., 2014. Antibacterial activity of new peptides from barbel protein hydrolysates and mode of action via a membrane damage mechanism against Listeria monocytogenes. Journal of Functional Foods, 11:322-329. doi: 10.1016/j.jff.2014.10.006

Subramanian, S., Ross, N. W., MacKinnon, S. L., 2008. Comparison of antimicrobial activity in the epidermal mucus extracts of fish. Comparative Biochemistry and Physiology., 150:85-92. doi: 10.1016/j.cbpb.2008.01.011

Song, Ru., Wei, Rong-Bian., Luo, Hong-Yu., Wang, Dog-Feng., 2012. Isolation and characterization of an antibacterial peptide fraction from pepsin hydrolysate of Half-Fin Anchovy (Setipinna taty). Molecules, 17: 29802991. doi: $10.3390 /$ molecules 17032980

Sung, W.S., Lee, J., Lee, D.G., 2008. Fungicidal Effect of Piscidin on Candida albicans: Pore Formation in Lipid Vesicles and Activity in Fungal Membranes. Biological and Pharmaceutical Bulletin, 31(10): 1906-1910. doi: 10.1248/bpb.31.1906

Takahashi, K., 2004. Translational Medicine in Fish-derived Peptides: From Fish Endocrinology to Human Physiology and Diseases. Endocrine Journal, 51(1):1-17. doi: 10.1507/endocrj.51.1

Takahashi, K., Kawauchi, H., 2004. Fish-derived peptides: from fish to human physiology and diseases. Peptides, 25(10):1575-1576. doi: 10.1016/j.peptides.2004.06.021

Takahashi, K., Totsune, K., Murakami, O., Shibahara, S., 2004. Urocortins as cardiovascular peptides. Peptides, 25(10):1723-1731. doi: 10.1016/j.peptides.2004.04.018

Takei, Y., Hyodo, S., Katafuchi, T., Minamino, N., 2004a. Novel fish-derived adrenomedullin in mammals: structure and possible function. Peptides, 25(10):1643-1656. doi: 10.1016/j.peptides.2004.06.026

Takei, Y., Inoue, K., Ogoshi, M., Kawahara, T., Bannai, H., Miyano, S., 2004b. Identification of novel adrenomedullin in mammals: a potent cardiovascular and renal regulator. FEBS Lett, 556: 53-58. doi: 10.1016/S0014-5793(03)01368-1

Unniappan, S., Peter, R.E., 2005. Structure, distribution and physiological functions of ghrelin in fish. Comparative Biochemistry and Physiology, Part A140:396-408. doi: 10.1016/j.cbpb.2005.02.011

Valero, Y., Garcia-Alcàzar, A., Esteban, M.À., Cuesta, A., Chaves-Pozo, E., 2015. Antimicrobial response is increased in the testis of European sea bass, but not in gilthead seabream, upon nodavirus infection. Fish \& Shellfish Immunology, 44:203-213. doi: 10.1016/j.fsi.2015.02.015

Wang, T., Tan, S., Cai, Z., 2015. Characterization and expression of MHC class II alpha and II beta genes in mangrove red snapper (Lutjanus argentimaculatus). Molecular Immunology, 68:373-381. doi: 10.1016/j.molimm.2015.09.018 